\title{
Investigating Gastroprotective Potential of Liquisolid Curcumin against the Role of Endogenous Aggressive Factors and Oxidative Stress Markers
}

\author{
Vijay Sharma, ${ }^{1}$ Kamla Pathak ${ }^{2, *}$ \\ 1Department of Pharmaceutics, SGT College of Pharmacy, Shree Guru Gobind Singh Tricentenary University-Gurugram,Badli Road, \\ Gurugram, Haryana, INDIA. \\ ${ }^{2}$ College of Pharmacy Saifai, Uttar Pradesh University of Medical Sciences, Saifai, Etawah, Uttar Pradesh, INDIA.
}

\begin{abstract}
Background: The study investigated the efficacy of Liquisolid Curcumin (LSC) over curcumin for gastroprotective action against ethanol induced acute gastric ulcers and the modulation of endogenous oxidative stress markers, in Wistar rats (p.o). Materials and Methods: The experimental design comprised of six groups namely control (Treated with $0.1 \% \mathrm{w} / \mathrm{v} \mathrm{CMC)}$, disease control (Treated with absolute ethanol), positive control (Treated with omeprazole; $40 \mathrm{mg} / \mathrm{Kg}$ ), Test-1 (Treated with curcumin; $50 \mathrm{mg} / \mathrm{Kg}$ ); and Test- 2 and 3 groups treated with LSC equivalent to 25 and $50 \mathrm{mg} / \mathrm{Kg}$, respectively. Gastroprotection was assessed by ulcer index, total acid and gastric mucus. The oxidative stress markers estimated were malondialdehyde (MDA), tissue Glutathione (GSH), Catalase (CAT) and Superoxide Dismustase (SOD). Results: Oral administration of LSC caused significant $(P<0.01)$ reduction in gastric lesions in dose dependent manner. The total acidity lowering effect and protective effect on mucus layer was more than curcumin and comparable to omeprazole under the test conditions. Additionally, the LSC significantly increased the activity/levels of GSH, CAT and SOD and suppressed the MDA level in gastric mucosa $(P<0.05)$. Histological studies demonstrated superior morphological integrity of gastric mucosa via LSC. Conclusion: LSC demonstrated superior gastroprotection via suppression of gastric acid, restoration of free radical scavenging enzymes and reduction in the lipid peroxidase production in comparison to curcumin.
\end{abstract}

Key words: Curcumin, Liquisolid curcumin, Liquisolid compacts, Gastroprotection, Oxidative stress markers.

\section{INTRODUCTION}

Gastric ulcer is the result of an imbalance between aggressive factors and safeguarding of mucosal integrity through the endogenous protective mechanism. ${ }^{1}$ The severity of disease may lead to upper gastrointestinal hemorrhage and perforation leading to high mortality and morbidity rates. ${ }^{2}$ Several endogenous factors including high acid secretion and imperfect mucosal barrier contribute towards initiation and progression of the underlined disease. ${ }^{3}$ The etiology of gastric ulcers is also associated with $H$. pylori infection that imbalances pepsin secretion, reflux of bile component, formation of free radicals, mucus-bicarbonate barrier, surface active phospholipids, mucosal blood flow, cell renewal and migration, enzymatic and non-enzymatic antioxidants and some growth factors. ${ }^{4,5}$ Other factors include induction of proinflammatory TNF- $\alpha$ expression, Reactive Oxygen Species (ROS), neutrophil infiltration, increased lipid peroxidation and decreased glutathione activity. ${ }^{6}$

The treatment is primarily focused on limiting the hazardous effects of acid secretion, generation of ROS, as well as to regulate various oxidative stress markers and enzymatic activities. The
Submission Date: 19-07-2018; Revision Date: 19-12-2018; Accepted Date: 29-03-2019

DOI: 10.5530/ijper.53.3.85 Correspondence:

Dr. Kamla Pathak, Professor, College of Pharmacy, Uttar Pradesh University of Medical Sciences Saifai, Etawah, Uttar Pradesh- 206130, INDIA. Phone: +91-05688-276023 E-mail: kamlapathak5@ gmail.com

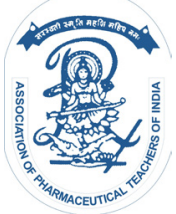

www.ijper.org 
long-term therapeutics based on proton pump inhibitors, prostaglandins, cytoprotective agents and histamine antagonists cause adverse drug reactions and the long-term use may result in changes in the biochemical architecture. Thus, the gastroprotective research has shifted its paradigm to molecules of natural origin, curcumin being one of them. ${ }^{7}$ Curcumin a phytoconstituent of Curcuma longa is a potent polyphenolic antioxidant recommended for the effective protection of gastric lesions and treatment of gastric ulcers. ${ }^{8}$ Presence of both phenolic $\mathrm{OH}$ and $\mathrm{CH}_{2}$ group of $\beta$-diketone moiety remarkably contribute to its antioxidant property. Curcumin inhibits generation of $\mathrm{H}_{2} \mathrm{O}_{2}$, in macrophages and directly lowers ${ }^{*} \mathrm{OH} .{ }^{9-10}$ Despite the fact that curcumin is therapeutically acclaimed it suffers from poor solubility $(0.6 \mu \mathrm{g} / \mathrm{mL})$ and dissolution ${ }^{11}$ and hence limited clinical efficacy. Pharmaceutical research has adopted various techniques to optimize the solubility of curcumin in order to improve its therapeutic efficacy. ${ }^{12-15}$

Liquisolid technique is a promising method that has been utilized to enhance the dissolution rate and bioavailability of various poorly water-soluble drugs. Our research on curcumin reported improved dissolution and bioavailability of curcumin using the potentials of liquisolid technology. The optimized liquisolid tablets exhibited higher cumulative drug release than the directly compressed tablets of curcumin. Furthermore, ex vivo permeation of curcumin through goat gastrointestinal mucosa was recorded to be significantly $(P<0.05)$ enhanced and its oral bioavailability was increased by 18.6-fold in New Zealand rabbits. In vitro cytotoxicity against NCL 87 cancer cells substantiated its anticancer efficacy. ${ }^{16}$ In continuation with the encouraging results, the present study was undertaken to comparatively investigate the antiulcer effect of optimized Liquisolid Curcumin (LSC) formulation against curcumin in ethanol induced gastric damage model. Additionally, the ulceroprotective activity was also assessed biochemically by monitoring various oxidative stress markers in Wistar rats.

\section{MATERIALS AND METHODS}

\section{Drugs and Chemicals}

Curcumin (Lot \# PC/CL/10LOT/09) was kindly supplied by Natural Remedies Private Limited (Bengaluru, India). Omeprazole was purchased from Biological E Ltd., India. Trichloroacetic acid and carboxy methyl cellulose were purchased from S. D. Fine Chemical Ltd. (Mumbai, India). Tris buffer solution was procured from Mivon Chemicals, Mumbai. Ethanol, Masson's
Trichrome Stain and 5, 5-dithiobis-2-nitro benzoic acid (DTNB) were purchased from Sigma Aldrich Ltd., U.S.A.

\section{Formulation of Liquisolid Curcumin}

A total of 12 liquisolid compositions using one nonvolatile solvent per group [Group -I (PEG 200); Group -II (PEG 400) and Group III (tween 80)] using MCC PH102 as a carrier material and Aerosil ${ }^{\mathbb{B}}$ as a coating material were formulated. The Ratio (R) of carrier and coating material used was 20:1, for all the systems. The $\Phi$ values calculated for carrier and coating material were utilized to determine the liquid Load Factor (L) and with the help of liquid load factor and amount of liquid medication (W), the appropriate amount of carrier and coating material was calculated as reported in Table 1.

For preparation, MCC PH102 was mixed with the drug liquid solution (Liquid medication). Blending was carried out for 2 min in a glass pestle mortar for even distribution of liquid medication in MCC PH102, during primary stage. In the secondary stage liquid-powder admixture was evenly spread as a uniform layer on the surface of the mortar and left for 5 min to allow sufficient adsorption of drug solution on to the surface of carrier particles. The damp, liquid-powder mixture was converted into the dry and freely flowing powder by the gradual addition of Aerosil ${ }^{\circledR}$ (coating material) with the continuous blending. Obtained product was termed as Liquisolid Curcumin (LSC). All the LSC were subjected to pre and post compression studies ${ }^{16}$ and the optimized liquisolid formulation was selected to be screened for its gastroprotective potential.

\section{Experimental Protocol}

The experimental protocol was approved by Institutional Animal Ethical committee vide letter no: IAEC/ RAP/03966. All the animal experiments were conducted in full compliance with the institutional ethical and regulatory principles and as per the spirit of Association for Assessment and Accreditation of Laboratory Animal Care and International's expectations for animal care and use/ethics committees. Wistar rats were randomly divided into six experimental groups (Group I, II, III, IV, V and VI), each containing six animals. Group I was designated as control, Group II (disease control), while Group III termed as positive control (Standard). Other groups were Group IV (Test-1), while Group V and VI were Test-2 and 3, respectively. All the rats were fasted for $24 \mathrm{~h}$ and deprived of water for $2 \mathrm{~h}$ before starting the treatment protocol. Initially, rats in each group were administered with $0.1 \% \mathrm{w} / \mathrm{v}$ CMC $(10 \mathrm{~mL} / \mathrm{Kg}$, p.o.). After $1 \mathrm{hr}$ Group II was treated with absolute ethanol 
(5mL/Kg BW, p.o.) and sacrificed by cervical dislocation under deep ether anesthesia, after $1 \mathrm{~h}$ of ethanol administration. Post one hour the rats of Group III were administered omeprazole ( $40 \mathrm{mg} / \mathrm{Kg}$, p.o.), Group IV was treated with curcumin $(50 \mathrm{mg} / \mathrm{Kg}$, p.o.), while Group V and VI was administered LSC equivalent to 25 and $50 \mathrm{mg}$ of curcumin $/ \mathrm{Kg}$ p.o., respectively to observe dose dependency. After $4 \mathrm{~h}$ of each treatment, the animals of Group III, IV, V and VI were administered absolute ethanol $(5 \mathrm{~mL} / \mathrm{Kg}$, p.o.) followed by euthanization by deep anesthesia using diethyl ether and sacrificed by cervical dislocation method. The stomach was immediately removed and the complete gastric content was collected by gently pressing the stomach. The stomach was opened along with greater curvature and rinsed with normal saline to wash out blood clots and adhered material to assess the extent of gastric damage.

\section{Ulcer Index}

The extent of gastric mucosal damage was observed and rated according to the ulcer score scale described by Dekanski et al. ${ }^{17}$ Ulcer Index (UI) was measured by following equation.

$U I=U_{N}+U_{S}+U_{P} \times 10^{-1}$

where, $\mathrm{U}_{\mathrm{N}}=$ Average number of ulcers/animal; $\mathrm{U}_{\mathrm{S}}=$ Average number of severity score; $\mathrm{U}_{\mathrm{P}}=$ Percentage of animals with ulcers. The Ulcer inhibition was calculated using eq, 2.

$\%$ Ulcer Inbibition $=\left[\left(\right.\right.$ U.I. ${ }_{\text {Non treated }}-$ U.I. $\left.{ }_{\text {Treated }}\right) /$ U.I. $\left.{ }_{\text {Non treated }}\right]$ $\times 100 \ldots \ldots \ldots(2)$

\section{Gastric Content}

The collected gastric content was centrifuged at 3000 rpm for $10 \mathrm{~min}$, the supernatant was collected and the volume of supernatant was measured. The supernatant samples were titrated (back titration) against $0.01 \mathrm{~mol} / \mathrm{L}$ sodium hydroxide $(\mathrm{NaOH})$ using phenolphthalein as indicator. ${ }^{18}$ The total acidity was expressed as milliequivalents using Eq. 3.

$$
\begin{aligned}
& \text { Total acidity }\left(\frac{m E q}{L}\right)=\frac{\mathrm{mL} \text { of } \mathrm{NaOH}}{\text { liter juice }} \times 50 \ldots \ldots \ldots \text {. (3) } \\
& \text { Gastric Mucus }
\end{aligned}
$$

The stomach tissues were soaked for $2 \mathrm{~h}$ in $0.1 \%$ alcian blue. Uncomplexed dye was removed by two successive washes of $0.25 \mathrm{M}$ sucrose at $15-$ and $45-\mathrm{min}$. Dye complexed with mucus was diluted by immersion in 10 $\mathrm{ml}$ aliquots of $0.5 \mathrm{M}$ magnesium chloride for $2 \mathrm{~h}$. The resulting blue solution was stirred with diethyl ether and the absorbance of the aqueous phase was measured at $580 \mathrm{~nm}$. The quantity of mucus was calculated by standard curves of alcian blue and the result expressed in mg of alcian blue/g tissue. ${ }^{19}$

\section{Assessment of Oxidative Stress in Tissues}

The levels of MDA (Malondialdehyde), GSH (Tissue glutathione), CAT (Catalase) and SOD (Super Oxide Dismutase) were measured to estimate the potential difference between LSC over curcumin on oxidative stress in ethanol induced gastric ulcer model. ${ }^{20}$ The stomach was weighed and homogenized in potassium phosphate buffer, $\mathrm{pH} 7.4$ and centrifuged (845.32 x g) for $15 \mathrm{~min}$. The supernatant was used for MDA and enzymatic assays.

\section{Estimation of Lipid Peroxide}

Lipid peroxide content in gastric mucosal tissue was determined by thiobarbituric acid reaction. ${ }^{21}$ The absorbance of the supernatant was read at $540 \mathrm{~nm}$ at room temperature against blank. The amount of MDA (nmol $\mathrm{MDA} / \mathrm{mg}$ protein) sample was calculated according to the eq. 4.

$$
\text { nmol of MDA }=\frac{\text { Absorbance at } 540 \mathrm{~nm} \times \text { final volume of test solution }}{0.156}
$$

\section{Estimation of tissue glutathione}

Five hundred milligrams of tissue was homogenized in $10 \mathrm{ml}$ of $200 \mathrm{mM}$ potassium phosphate buffer, $\mathrm{pH} 6.5$ and $50 \% \mathrm{v} / \mathrm{v}$ trichloroacetic acid was added to the aliquot. Homogenized, vortex for $10 \mathrm{~min}$ and then centrifuged $(3381.3 \mathrm{x}$ g). 0.4 M Tris buffer and 0.01M, DTNB was added to supernatant ${ }^{22}$ and absorbance was measured at $415 \mathrm{~nm}$. The amount of GSH $(\mu \mathrm{g} / \mathrm{mg}$ of protein) was calculated by the following equation 5 ,

$G S H=\frac{\text { Absorbance at } 412 \mathrm{~nm} \times 50 \times \times 3.5 \times \times 2.25 x \times 1}{0.337 \times 2 \times \mathrm{mg} \text { of protein }}$.

Blank determination was carried out without tissue homogenate.

\section{Estimation of catalase activity}

Fifty milliliters of the supernatant was added to the cuvette containing $2.95 \mathrm{ml}$ of $19 \mathrm{mM} / \mathrm{L}$ solution of $\mathrm{H}_{2} \mathrm{O}_{2}$ prepared in potassium phosphate buffer, $\mathrm{pH} 6.4$. The change in absorbance was monitored at $240 \mathrm{~nm}$ at $1 \mathrm{~min}$ interval for $3 \mathrm{~min} .{ }^{23}$ Catalase activity (nmol of $\mathrm{H}_{2} \mathrm{O}_{2}$ consumed/ $\mathrm{min} / \mathrm{mg}$ protein) was calculated by equation 6 .

Catalase activity $=\frac{\text { Decrease in absorbance per min } X \text { volume of assay }}{0.081 \mathrm{X} \text { volume of homgenate } \mathrm{X} \mathrm{mg} \mathrm{of} \mathrm{protein}}$

\section{Estimation of superoxide dismutase activity}

Supernatant was assayed for SOD activity by following the inhibition of pyrogallol autoxidation. ${ }^{24}$ SOD activity (SOD units per $\mathrm{mg}$ of protein) was calculated according SOD unit per ml of sample $=\frac{(A \times B) \times 100}{A \times 50}$

where, $\mathrm{A}$ is the absorbance difference in control in 1 min and $\mathrm{B}$ is the absorbance difference in test sample. 


\section{Histology}

The specimens of tissues were collected from the preserved stomachs of rats. Tissue fragments were stained with hematoxylin and eosin and Masson's trichome. The studies were carried out by light microscopy $(40 \mathrm{X})$ for the assessment of histological changes.

\section{Statistical Analysis}

The obtained data was subjected to one-way Analysis of Variance (ANOVA) followed by Dunnett's Test using the GraphPad Prism V5.0 (GraphPad Software, Inc., San Diego, California, USA). The $P$ values of $<0.01$ were considered as highly significant, while $P$ values $<$ 0.05 were considered as statistically significant.

\section{RESULTS}

\section{Effect of LSC on Gastric Lesions}

Macroscopic analysis revealed absence of lesions in control group I (Figure 1A). The animals of Group II showed macroscopic damage that was evidenced by the presence of ulcerative hemorrhage (Figure 1B) with the clear appearance of erosive and ulcerative linear gastric lesions. Disruption of the surface epithelium with bleeding, deep necrotic lesions into the mucosa and edema of the sub-mucosal layer with redness was clearly observed. On the other hand the gastric mucosa of the rats treated with standard drug omeprazole (Group III) was apparently normal in appearance (Figure 1C). The animals of Group IV (Test Group-1) were able to reverse the damage, up to some extent as assessed by the change in colour of stomach from red to dark pink with less hemorrhagic streaks and substantial damage of mucosa (Figure 1D). On the other hand, Group V (Test-2), did not evidence macroscopic toxicity as the morphological integrity of the gastric mucosa with retained and the necrosis of the mucosal surface was absent (Figure 1E). On comparing the results of Group IV and V, treated with two different forms of curcumin i.e. curcumin (50 $\mathrm{mg} / \mathrm{Kg})$ and LSC $(25 \mathrm{mg} / \mathrm{Kg})$ respectively, better gastric protection was evidenced in Group V. Furthermore, Group VI (Test-3) treated with double dose of LSC $(50 \mathrm{mg} / \mathrm{Kg}$ ) completely reversed the lesions with the score of 1.5 (Figure $1 \mathrm{~F}$ ), a perfect pink to red colored stomach and no sign of damage was recorded as with standard control group (Figure 1C), indicating dose dependent effect of LSC on gastroprotection.

Additionally, the gastric lesions were judged by measuring the ulcer index and the data is given in Table 2 . The ulcer control group displayed highest value of ulcer index $27.4 \pm 4.6$ that was followed by Group IV (treated with curcumin). The ulcer index of curcumin treated group was almost 1.5 times lower than ulcer control group suggesting effective gastroprotection by curcumin. However, it was not as effective as omeprazole. On the other hand Group V and VI, treated with LCS showed a significant decrease $(P<0.01)^{\#}$, in ulcer index as compared to Ulcer control group. Correspondingly, oral administration of omeprazole, LSC at 25 and 50 $\mathrm{mg} / \mathrm{Kg}$ showed $88.32,84.67$ and $86.86 \%$ ulcer inhibition, respectively that was $\approx 2.5$ times more than curcumin $(32.84 \%)$.

\section{Gastric Content}

In the ulcer control group, administration of ethanol caused a significant increase $(P<0.01)^{*}$ in the gastric secretion volume to the tune of $2.84 \pm 0.10 \mathrm{~mL}$ as compared to Group I $(1.68 \pm 0.08 \mathrm{~mL})$. However, administration of omeprazole significantly reduced $(P<0.01){ }^{\#}$ the gastric secretions (Table 2), which was not observed in Group IV treated with curcumin. Paradoxically the gastric secretion volume $(2.16 \pm 0.12 \mathrm{~mL})$ was almost comparable to that of group II. In contrast, LSC showed remarkable reduction in the gastric secretion volume with significant reduction $(P<0.01)$ in both the doses of $25 \mathrm{mg} / \mathrm{Kg}(1.64 \pm 0.04 \mathrm{~mL})$ and $50 \mathrm{mg} / \mathrm{Kg}(1.42 \pm 0.08$ $\mathrm{mL}$ ). Remarkably the volumes were similar for both the doses.

Another parameter that was evaluated was gastric acidity that was approximately two-fold higher (8.84 \pm 0.64 $\mathrm{mEq} / \mathrm{L}$ ) in Group II (Ulcer control), in comparison to the control Group I $(4.82 \pm 0.11 \mathrm{mEq} / \mathrm{L})$. On omeprazole treatment the value got significantly decreased $(P<0.01)^{\#}$ to $4.23 \pm 0.12 \mathrm{mEq} / \mathrm{L}$. Treatment with curcumin reduction in the acidity level up to some extent $(P>0.05)^{\mathrm{ns}}$ (Table 2), while administration of LSC (25 and $50 \mathrm{mg} / \mathrm{Kg})$ showed significant $(P<0.01)$ reduction in gastric acidity $(4.85 \pm 0.13$ and $3.96 \pm 0.09 \mathrm{mEq} / \mathrm{L}$, respectively).

On comparative analysis of mucus content, oral administration of ethanol had a detrimental effect on gastric mucus wall and caused a significant depletion $(P<0.01)$ in the mucus content $(118.9 \pm 14.92 \mathrm{mg} / \mathrm{g})$ as compared to control $(209.5 \pm 12.62 \mathrm{mg} / \mathrm{g}$ ) and Group III (omeprazole treated; $198.0 \pm 15.07 \mathrm{mg} / \mathrm{g}$ ). While LSC showed protective effect on mucus layer especially in Group VI, with the total mucus content of $196.4 \pm 15.03 \mathrm{mg} / \mathrm{g}$ of stomach, similar to omeprazole treatment. However, curcumin treatment (Group IV) did not offer protect to the extent LCS could do.

\section{Oxidative Stress Markers}

In reference to the control, administration of ethanol significantly increased the levels of MDA $(P<0.01)$, by 


\begin{tabular}{|c|c|c|c|c|c|c|c|}
\hline \multicolumn{7}{|c|}{ Table 1: Formulation Details of Liquisolid Curcumin (LSC1 - LSC12). } \\
\hline $\begin{array}{c}\text { GROUP } \\
\text { No. }\end{array}$ & $\begin{array}{c}\text { Formulation } \\
\text { Code }\end{array}$ & $\begin{array}{c}\text { Drug } \\
(\% \text { w/w) }\end{array}$ & R = Q/q & $\begin{array}{c}\text { Nonvolatile solvent } \\
\text { (W) } \\
(\mathbf{m g})\end{array}$ & $\begin{array}{c}\text { Liquid load } \\
\text { factor } \\
\text { (Lf) }\end{array}$ & $\begin{array}{c}\text { Carrier } \\
\text { material } \\
(\mathbf{Q})\end{array}$ & $\begin{array}{c}\text { Coating } \\
\text { material } \\
(\mathbf{q})\end{array}$ \\
\hline Group - I & LSC-1 & 40 & $20: 1$ & 150.00 & 0.27 & 538.50 & 26.92 \\
\hline & LSC-2 & 50 & $20: 1$ & 100.00 & 0.27 & 359.06 & 17.95 \\
\hline & LSC-3 & 60 & $20: 1$ & 67.75 & 0.27 & 239.49 & 11.97 \\
\hline & LSC-4 & 70 & $20: 1$ & 42.85 & 0.27 & 153.86 & 7.69 \\
\hline Group - II & LSC-5 & 40 & $20: 1$ & 150.00 & 0.28 & 535.71 & 26.78 \\
\hline & LSC-6 & 50 & $20: 1$ & 100.00 & 0.28 & 357.14 & 17.85 \\
\hline & LSC-7 & 60 & $20: 1$ & 67.75 & 0.28 & 238.21 & 11.91 \\
\hline & LSC-8 & 70 & $20: 1$ & 42.85 & 0.28 & 153.03 & 7.65 \\
\hline Group - III & LSC-9 & 40 & $20: 1$ & 150.00 & 0.35 & 425.53 & 26.78 \\
\hline & LSC-10 & 50 & $20: 1$ & 100.00 & 0.35 & 283.68 & 17.85 \\
\hline & LSC-11 & 60 & $20: 1$ & 67.75 & 0.35 & 189.21 & 11.91 \\
\hline & LSC-12 & 70 & $20: 1$ & 42.85 & 0.35 & 121.56 & 7.65 \\
\hline
\end{tabular}

Non-volatile solvent used: PEG 200 (Group - I; LSC1 - LSC4); PEG 400 (Group -II; LSC5 - LSC8);

Tween 80 (Group -III; LSC9 - LSC12).

\begin{tabular}{|c|c|c|c|c|c|c|}
\hline $\begin{array}{l}\text { Group } \\
(n=6)\end{array}$ & Treatment & $\begin{array}{l}\text { Ulcer } \\
\text { index } \\
\text { score }\end{array}$ & $\begin{array}{c}\text { Ulcer } \\
\text { Inhibition (\%) }\end{array}$ & $\begin{array}{l}\text { Gastric juice } \\
\text { volume } \\
(\mathrm{mL})\end{array}$ & $\begin{array}{c}\text { Total gastric } \\
\text { acidity } \\
\text { (mEq/L) }\end{array}$ & $\begin{array}{c}\text { Mucus } \\
\text { (mg/g stomach) }\end{array}$ \\
\hline $\begin{array}{l}\text { Group I } \\
\text { (Control) }\end{array}$ & $0.1 \% \mathrm{w} / \mathrm{v}$ CMC $(10 \mathrm{~mL} / \mathrm{Kg})$ & 0.00 & ---- & $1.68 \pm 0.08$ & $4.82 \pm 0.11$ & $209.5 \pm 12.62$ \\
\hline $\begin{array}{c}\text { Group II } \\
\text { (Ulcer control) }\end{array}$ & $\begin{array}{l}\text { Absolute ethanol }(5 \mathrm{~mL} / \\
\mathrm{Kg})\end{array}$ & $\begin{array}{c}27.4 \pm \\
4.6^{*}\end{array}$ & ---- & $2.84 \pm 0.10^{*}$ & $8.84 \pm 0.64^{*}$ & $118.9 \pm 14.92^{*}$ \\
\hline $\begin{array}{l}\text { Group III } \\
\text { (Standard } \\
\text { Control) }\end{array}$ & Omeprazole (40 mg/Kg) & $\begin{array}{l}2.8 \pm \\
0.8^{\#}\end{array}$ & 88.32 & $1.12 \pm 0.06^{\#}$ & $4.23 \pm 0.12^{\#}$ & $198.0 \pm 15.07^{\#}$ \\
\hline $\begin{array}{c}\text { Group IV } \\
\text { (Test Group-1) }\end{array}$ & Curcumin $(50 \mathrm{mg} / \mathrm{Kg})$ & $\begin{array}{c}18.4 \pm \\
2.4^{* \#}\end{array}$ & 32.84 & $2.16 \pm 0.12^{*}$ & $6.98 \pm 0.19^{\text {ns }}$ & $146.7 \pm 12.64^{*}$ \\
\hline $\begin{array}{c}\text { Group V } \\
\text { (Test Group -2) }\end{array}$ & $\begin{array}{l}\text { LSC equivalent to } 25 \mathrm{mg} / \\
\mathrm{Kg} \text { of curcumin }\end{array}$ & $4.2 \pm 0.6^{\#}$ & 84.67 & $1.64 \pm 0.04^{\#}$ & $4.85 \pm 0.13^{\#}$ & $179.3 \pm 16.23^{\#}$ \\
\hline $\begin{array}{c}\text { Group VI } \\
\text { (Test Group-3) }\end{array}$ & $\begin{array}{l}\text { LSC equivalent to } 50 \mathrm{mg} / \\
\mathrm{Kg} \text { of curcumin }\end{array}$ & $2.9 \pm 0.4^{\#}$ & 86.86 & $1.42 \pm 0.08^{\#}$ & $3.96 \pm 0.09^{\#}$ & $196.4 \pm 15.03^{\#}$ \\
\hline
\end{tabular}

All the values are expressed as mean $\pm S D$. Levels of statistical significance were determined by One - Way ANOVA followed by Dunnett's significant difference. * indicates Significant in comparison to Group I, \# indicates Significant, as compared to Group II, ns indicates Non-significant.

almost three-fold (Table 3). Treatment with omeprazole showed a reduction in MDA level $(0.614 \pm 0.036 \mathrm{nmol} /$ mg protein) to approximately half of the value, exhibited by ethanol treatment II $(1.232 \pm 0.312 \mathrm{nmol} / \mathrm{mg}$ protein). Curcumin treatment demonstrated a decrease in MDA levels but to a lesser extent than omeprazole treatment. In contrast the levels of MDA in test Group $\mathrm{V}$ and VI treated with LSC, were significantly attenuated
$(P<0.01)$ as compared to ulcer control Group II. The attenuation was dose dependent.

In reference to control, the level of GSH and markers of free radical scavenging enzymes CAT and SOD decreased significantly $(P<0.01)$ in group II. Treatment with Omeprazole elicited reversal of the markers comparable to the levels of control group. Furthermore, treatment with curcumin (Group IV) displayed resto- 


\begin{tabular}{|c|c|c|c|c|}
\hline $\begin{array}{l}\text { Treatment group } \\
\qquad(n=6)\end{array}$ & $\begin{array}{c}\text { MDA } \\
\text { (nmol MDA/mg protein) }\end{array}$ & $\begin{array}{c}\text { GSH } \\
(\mu \mathrm{g} / \mathrm{mg} \text { of protein) }\end{array}$ & $\begin{array}{c}\text { CAT } \\
\text { (nmol of } \mathrm{H}_{2} \mathrm{O}_{2} \text { consumed/ } \\
\mathrm{min} / \mathrm{mg} \text { protein) }\end{array}$ & $\begin{array}{c}\text { SOD } \\
\text { (SOD units per mg of } \\
\text { protein) }\end{array}$ \\
\hline $\begin{array}{l}\text { Group I } \\
\text { (Control) }\end{array}$ & $0.427 \pm 0.024$ & $18.76 \pm 1.042$ & $0.163 \pm 0.008$ & $0.582 \pm 0.023$ \\
\hline $\begin{array}{c}\text { Group II } \\
\text { (Ulcer Control) }\end{array}$ & $1.232 \pm 0.312^{*}$ & $4.864 \pm 1.446^{*}$ & $0.050 \pm 0.014^{*}$ & $0.262 \pm 0.036^{*}$ \\
\hline $\begin{array}{c}\text { Group III } \\
\text { (Standard Control) }\end{array}$ & $0.614 \pm 0.036^{\#}$ & $15.96 \pm 1.622^{\#}$ & $0.145 \pm 0.043^{\#}$ & $0.514 \pm 0.060^{\#}$ \\
\hline $\begin{array}{c}\text { Group IV } \\
\text { (Test Group - 1) }\end{array}$ & $0.997 \pm 0.012^{*}$ & $9.04 \pm 1.893^{*}$ & $0.084 \pm 0.048^{*}$ & $0.386 \pm 0.089 *$ \\
\hline $\begin{array}{c}\text { Group V } \\
\text { (Test Group - 2) }\end{array}$ & $0.698 \pm 0.028^{\#}$ & $12.961 \pm 1.022^{\#}$ & $0.138 \pm 0.054^{\#}$ & $0.491 \pm 0.047^{\#}$ \\
\hline $\begin{array}{c}\text { Group VI } \\
\text { (Test Group - 3) }\end{array}$ & $0.592 \pm 0.022^{\#}$ & $15.48 \pm 1.226^{\#}$ & $0.151 \pm 0.062^{\#}$ & $0.522 \pm 0.026^{\#}$ \\
\hline
\end{tabular}

All the values are expressed as mean $\pm S D$. * indicates Statistically significant difference in comparison to Group I, \# indicates Statistically significant difference, as compared to Group II.
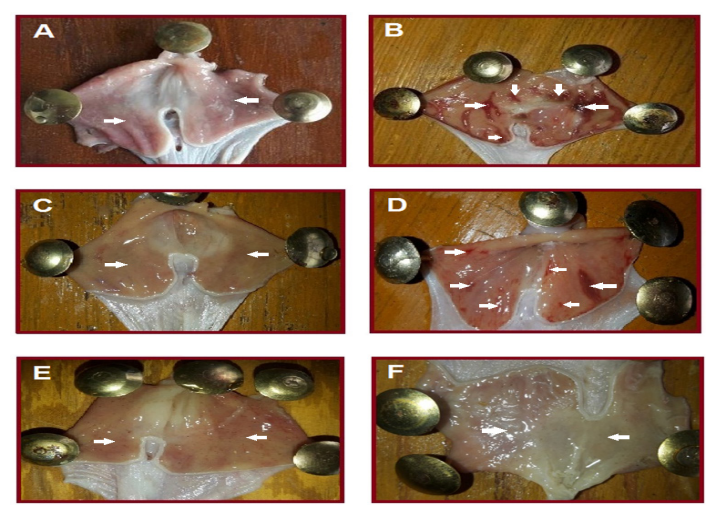

Figure 1: Gross Macroscopic Evaluation of Gastric Lesions: (A) Group I (Normal Control); (B) Group II (Ulcer Control) administered with ethanol (5mL/Kg BW p.o.); (C) Group III (Standard Control) administered with omeprazole (40mg/Kg BW p.o.); (D) Group IV (Test Group 1) administered with pure curcumin (50 mg/Kg BW p.o.); (E) Group V (Test Group 2) administered with LSC (equivalent to $25 \mathrm{mg}$ of curcumin $/ \mathrm{Kg}$ BW p.o.); (F) Group VI (Test Group 3) administered with LSC (equivalent to $50 \mathrm{mg}$ of curcumin $/ \mathrm{Kg} \mathrm{BW} \mathrm{p.o.).}$

ration of the depleted level of GSH, CAT and SOD (Table 3) when compared to Group II, but less significantly $(P<0.05)$ in comparison to Group V and VI. The restoration particularly for CAT and SOD levels in Group V and VI was less as compared to standard treatment of omeprazole in Group III. As recorded, Group III significantly $(P<0.01)$ restored the levels of GSH and SOD, but the restoration in the depleted level of CAT was less significant $(P<0.05)$ as compared to Group V and VI.

\section{Histology}

The control Group I showed the presence of normal gastric mucosa that contained crypts of overlying gas-
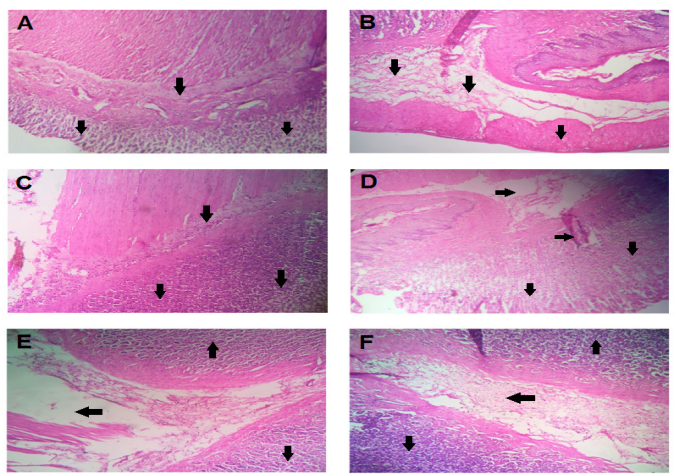

Figure 2: Histological Evaluation of Gastric Lesions Under Microscope at 40X: (A) Group I (Normal Control); (B) Group II (Ulcer Control) administered with ethanol ( $5 \mathrm{~mL} / \mathrm{Kg}$ BW p.o.); (C) Group III (Standard Control) administered with omeprazole (40mg/Kg BW p.o.); (D) Group IV (Test Group 1) administered with pure curcumin (50 $\mathrm{mg} / \mathrm{Kg} \mathrm{BW} \mathrm{p.o.);} \mathrm{(E)} \mathrm{Group} \mathrm{V}$ (Test Group 2) administered with LSC (equivalent to $25 \mathrm{mg}$ of curcumin/Kg BW p.o.); (F) Group VI (Test Group 3) administered with LSC (equivalent to $50 \mathrm{mg}$ of curcumin $/ \mathrm{Kg} \mathrm{BW} \mathrm{p.o.).}$

tric glands lined by mucus secreting cells with rounded nuclei. The lamina propria was intact, infiltrated by scattered lymphocytes, blood vessels and fibrous tissue (Figure 2A). Group II exhibited severe injuries on mucosal layer and produced the characteristic zone of necrotizing mucosal lesions with severe microscopic gastric mucosal damage. Necrosis hemorrhage and focal ulceration in superficial mucosal epithelium with inflammatory cell infiltration and congestion of blood vessels in sub-mucosa is apparent in Group II (Figure 2B). In comparison to Group II, Group III recovered the ulcer base with restored surface epithelium (Figure 2C), validated by decreased ulcer score (Table 2). In Group IV, the surface mucus cells more or less restored (Fig- 
ure 2D), while Group V and VI successfully reverted the mucosal damage, endorsed by absence of chronic inflammatory cells and recovery of surface mucosal cells (Figure 2E and F).

\section{DISCUSSION}

The gastroprotective effectiveness of LSC over curcumin was evaluated in ethanol induced inflammatory model in Wistar rats. The model selection was based on the fact that ethanol promotes oxidative stress, both by increasing the formation of ROS and depleting the oxidative defense mechanism in the cell. ${ }^{25}$ Additionally, it also induces TNF- $\alpha$ expression for neutrophil mediated ROS generation as well as for apoptosis. ROS mediated induction of lipid peroxidation and protein oxidation are primarily involved in the pathogenesis of ethanol induced ulcers in the gastric mucosa and free radical scavenging is one of the mechanism implicated in the healing of gastric ulcers. ${ }^{26}$ Preventive antioxidants such as SOD and GSH act as the first line of defense that prevents the destructive action of oxidative damage. The superoxide radical reacts with the cellular lipids, leading to the formation of lipid peroxide which gets metabolized to MDA. ${ }^{27}$ Ethanol induced damage to gastric mucosa is coupled with significant depletion in the levels of sulphydryl compounds, especially GSH. ${ }^{28}$ This decrease in the level of GSH results in enhanced lipid peroxidation which causes increased GSH consumption. In contrast, an increase in gastric non-protein sulphydryl content limits the production of oxygen derived free radicals and could be related to gastric protection in ethanol induced ulcer model. Malondialdehyde being a degradation product of unsaturated fatty acids and a biomarker of oxidative stress, measurement of gastric MDA level can be utilized for indirect estimation of lipid peroxidation. ${ }^{29}$

Curcumin, a highly potent polyphenolic antioxidant decreases ethanol induced increased gastric acid levels, which is beneficial to prevent acid-induced aggravation of ulcers. ${ }^{30}$ As shown in Table 2, significant reduction in ulcer index, gastric juice volume as well as total gastric acidity and enhancement in ulcer inhibition along with increased mucus secretion by the mucosal cells of the stomach was observed in the groups treated with omeprazole/LSC (Group III, V and VI), in reference Group II (Ulcer control). Curcumin, on the other hand demonstrated lesser activity which may be attributed to its poor solubility. LSC with higher solubility than curcumin affected higher dissolution of the active and hence superior therapeutic efficacy. ${ }^{16}$
The mucoprotective potential of LSC over is an indicative of amelioration. Curcumin also accelerates the ulcer healing phenomenon by inhibiting gastric acid secretion and anti-inflammatory activity preventing inducible TNF- $\alpha$ production at post-transcriptional level and affecting oxidative stress along with total antioxidant capacity, as well as by inhibiting IL-6 secretion and preventing apoptosis. ${ }^{31}$ LSC exhibited significant $(P<0.01)$ protective and ulcer inhibition efficacy in a dose dependent manner ( 25 and $50 \mathrm{mg} / \mathrm{Kg}$ ), which was non-significant $(P>0.05)$ in case of pure curcumin even at similar highest concentration $(50 \mathrm{mg} / \mathrm{Kg})$, which could be due to its poor solubility/absorption that resulted as failure in strengthening of defensive mechanism.

In particular, generation of oxygen free radicals and lipid peroxidation plays a key role in ethanol induced development of gastric lesions. The oxidative stress in gastric tissue causes damage to key biomolecules (Lipids) which is apparent from the stimulated lipid oxidation leading to increased accumulation of MDA (Table 3) and these increased levels of MDA are thought to reflect free radical mediated cell membrane damage. ${ }^{32}$ Glutathione is tripeptide and important non-enzymatic cytosolic antioxidant, acts as a reductant and cofactor for some antioxidant enzymes. ${ }^{33} \mathrm{GSH}$ and other antioxidants plays crucial role in free radical degradation, which would otherwise outcome of lipid peroxidation. ${ }^{34}$ The endogenous antioxidant enzymes, CAT and SOD in the gastric mucus are the key component of cellular defense system against ROS. However, SOD destroys the highly reactive radical superoxide by converting it into the less reactive peroxide, $\mathrm{H}_{2} \mathrm{O}_{2}$ which can be destroyed by CAT reaction. ${ }^{35}$ CAT is a highly reactive enzyme that reacts with $\mathrm{H}_{2} \mathrm{O}_{2}$ to form water and molecular oxygen. Decreased activity of GST, CAT and SOD (Table 3) after ethanol administration may be due to enhancement of MDA, which inhibit protein synthesis and activities of certain enzymes. Vice-versa decreased intrinsic oxidative stress in gastric mucosa by increased GSH availability results in lowering of peroxide production and hence reduces the level of MDA. ${ }^{36}$ This decrease might be due to elevated level of TNF- $\alpha$ in gastric tissue of ethanol treated rats. ${ }^{37}$

Administration of LSC significantly enhanced the activity of GSH, CAT and SOD in a dose dependent manner, probably due to prevention of accumulation of excessive free radicals thereby protecting stomach from damage, suggesting superior gastro-protective activity in comparison to curcumin that exhibited poorly significant enhancement $(P>0.05)$ in enzyme levels. The marked effect of LSC could be attributed to its high radical scavenging activity ${ }^{38}$ which is probably due to 
contribution of large number of molecules available in the system (Gastric media), due to enhanced dissolution. Curcumin attenuated the increased lipid peroxidase damage and prevented the depletion of GSH, CAT and SOD made by ethanol up to an extent with a highly significant difference $(P<0.01)$, when compared to omeprazole. In contrast, LSC increased the levels of these circulating factors close to control (Group I) and Group III non-significantly ( $P>0.05)$, supporting the hypothesis of improved solubility of curcumin via LSC. Being a poly phenolic aromatic compound, curcumin bears ability of scavenging the reactive free radicals either from phenolic - $\mathrm{OH}$ group or $-\mathrm{CH}_{2}$ group of the $\beta$-diketone moiety. ${ }^{39}$ Since, reactive free radicals can undergo electron transfer or abstract $\mathrm{H}$-atom from either of these two sites. Some studies reported that antioxidant activity of curcumin is due to phenolic -OH group. ${ }^{40}$ However, some studies suggest that hydrogen abstraction from the $-\mathrm{CH}_{2}$ group is responsible for its antioxidant activity. ${ }^{41}$ The said mechanism can be proposed for LSC, whereby high concentration of curcumin molecules from LSC afforded higher antioxidant activity than pure curcumin as evident in Table 3 . Another research claims effective blockage of ethanol induced overproduction of ${ }^{*} \mathrm{OH}$ to prevent $\mathrm{ROS}$ mediated gastric lesions. In addition to $\mathrm{H}_{2} \mathrm{O}_{2},{ }^{*} \mathrm{OH}$ is also formed from peroxynitrite generated from $\mathrm{O}_{2}{ }^{-}$and $\mathrm{NO}$. LSC thus offers further defense against oxidative damage by scavenging ${ }^{*} \mathrm{OH}$ generated from other sources. ${ }^{*} \mathrm{OH}$, being most reactive can interact with almost any compound in the cell including lipid, protein, DNA, carbohydrate, thiols and other low molecular weight antioxidants. ${ }^{42}$ This is how ${ }^{*} \mathrm{OH}$ is scavenged with ultimate oxidation of macromolecules and antioxidants, lead to pathogenesis. The chemical structure of curcumin is suitable for interaction with free radicals and it's *OH-scavenging effect has been demonstrated. ${ }^{43}$ However, direct scavenging of ${ }^{*} \mathrm{OH}$ can be considered an important pleiotropic effect of curcumin for gastroprotection, which enhances its potential for possible use as an antiulcer compound.

Histological evidences further substantiate the superiority of LSC for gastroprotection over curcumin. Upon ethanol administration, the back-diffusion of gastric acid into the mucosal wall could directly lead to vascular leakage and aggressive damaging effect in the basement membrane of both epithelial and mucosal cells in the gastric wall. ${ }^{44}$ Furthermore, brief cessation of mucosal blood flow results in increased acidity, which in turn, results in the formation of hemorrhagic erosions after ethanol treatment. ${ }^{45}$ Omeprazole treatment recovered the ulcer base with restored surface epithelium that was validated by decreased ulcer score (Table 2). Curcumin treatment was also effective in restoration however, LSC treatment successfully reverted the mucosal damage, endorsed by absence of chronic inflammatory cells and recovery of surface mucosal cells. This confirms superior therapeutic efficacy of LSC over curcumin.

\section{CONCLUSION}

Liquisolid curcumin demonstrated significant gastroprotection in comparison to pure curcumin. The improved gastroprotective action may be due to high solubility of the former that resulted in strengthening of gastric mucosa, restoring the free radical scavenging enzymes and reducing the lipid peroxide production, efficiently. The results revealed that treatment with liquisolid curcumin resulted in maintaining the integrity of gastric mucosa by attenuating the histological changes comparable to the effects exhibited by omeprazole. The present research proves that liquisolid technology is a simple, cost effective and commercially viable technique which may be attractive to industrialists due to its promising outcomes.

\section{ACKNOWLEDGEMENT}

Authors are thankful to Natural Remedies Private Limited, Bengaluru, India for providing free sample of curcumin, to carry out the present research work.

\section{CONFLICT OF INTEREST}

The authors report no conflicts of interest.

\section{ABBREVIATIONS}

LSC: Liquisolid curcumin; ROS: Reactive oxygen species; MDA: Malondialdehyde; GSH: Tissue glutathione; CAT: Catalase; SOD: Super oxide dismutase.

\section{REFERENCES}

1. Golbabapour S, Hajrezaie H, Hassandarvish P, Majid NA, Hadi AHA, Nordin $\mathrm{N}$, et al. Acute toxicity and gastroprotective role of $M$. pruriens in ethanol induced gastric mucosal injuries in rats. BioMed Res Int. 2013;4:1-13.

2. Thamotharan G, Sekar G, Ganesh T, Sen S, Chakraborty R, Kumar NS. Antiulcerogenic effect of Lanatacamara Linn leaves on in vivo test models in rats. Asian J Pharm Clin Res. 2010;3(3):57-60.

3. Khushtar M, Kumar V, Javed K, Bhandari U. Protective effect of ginger oil on aspirin and pylorus ligation-induced gastric ulcer model in rats. Ind J Pharm Sci. 2009;71(5):563-7.

4. Dhiyaaldeen SM, Amin ZA, Darvish PH, Mustafa IF, Jamil MM, Rouhollahi $\mathrm{E}$, et al. Protective effects of (1-(4-hydroxy-phenyl)-3-mtolyl-propenone chalcone in indomethacin induced gastric erosive damage in rats. BMC Vet Res. 2014;10(1):1-14.

5. Allen A, Flemstrom G. Gastroduodenal mucus bicarbonate barrier: Protection against acid and pepsin. AJP Cell Physiology. 2005;288(1):C1-19. 
6. Halliwell B, Gutteridge JMC. Role of free radicals and catalytic metal ions in human disease: An overview. Methods Enzymol. 1990;186:1-85.

7. Shoaib A, Tarique M, Khushtar M, Siddiqui HH. Anti-ulcerogenic activity of hydromethanolic extract of Andrographis paniculata in indomethacin and indomethacin plus pylorus ligation induced gastric ulcer in rats. Asian $\mathrm{J}$ Biomed Pharm Sci. 2014;4(39):8-15.

8. Yadav SK, Sak AK, Jha RK, Sah P, Shah DK. Turmeric (curcumin) remedies gastroprotective action. Pharmacogn Rev. 2013;7(13):42-6. doi: 10.4103/0973-7847.112843

9. Chattopadhyay I, Bandyopadhyay U, Biswas K, Maity P, Banerjee RK. Indomethacin inactivates gastric peroxidase to induce reactive-oxygen mediated gastric mucosal injury and curcumin protects it by preventing peroxidase inactivation and scavenging reactive oxygen free radical. Biol Med. 2006;40(8):1397-408.

10. Tuorkey M, Karolin K. Anti-ulcer activity of curcumin on experimental gastric ulcer in rats and its effect on oxidative stress/antioxidant, IL-6 and enzyme activities. Biomed Environ Sci. 2009;22(6):488-95.

11. Kurien BT, Singh A, Matsumoto $\mathrm{H}$, Scofield RH. Improving the solubility and pharmacological efficacy of curcumin by heat treatment. Assay Drug Dev Technol. 2007;5(4):567-76.

12. Akbar MU, Zia KM, Nazir A, Iqbal J, Ejaz SA, Akas MSH. Pluronic-based mixed polymeric micelles enhance the therapeutic potential of curcumin. AAPS Pharm Sci Tech. 2018;19(6):2719-39. https://doi.org/10.1208/ s12249-018-1098-9.

13. Rachmawati H, Edityaningrum CA, Mauludin R. Molecular inclusion complex of curcumin- $\beta$-cyclodextrin nanoparticle to enhance curcumin skin permeability from hydrophilic matrix gel. AAPS Pharm Sci Tech. 2013;14(4):1303-12. https://doi.org/10.1208/s12249-013-0023-5.

14. Jaisamut P, Wiwattanawongsa K, Graidist P, Sangsen $Y$, Wiwattanapatapee $R$. Enhanced oral bioavailability of curcumin using a supersaturatable selfmicro emulsifying system incorporating a hydrophilic polymer; in vitro and in vivo investigations. AAPS Pharm Sci Tech. 2018;19(2):730-40. https://doi. org/10.1208/s12249-017-0857-3.

15. Nadaf SJ, Killedar SG. Curcumin nanocochleates: Use of design of experiments, solid state characterization, in vitro apoptosis and cytotoxicity against breast cancer MCF-7 cells. J Drug Deliv Sci Tech. 2018;47:337-50.

16. Sharma V, Pathak K. Effect of hydrogen bond formation/replacement on solubility characteristics, gastric permeation and pharmacokinetics of curcumin by application of powder solution technology. Acta Pharm Sin B. 2016;6(6):600-13.

17. Dekanski JB, MacDonald A, Sacra P. Effects of fasting, stress and drugs on gastric glycoprotein synthesis in the rat. Br J Pharmacol. 1975;55(3):387-92.

18. Sohair RS, Mahmoud AA, Mohammad HA. Ameliorative effect of the sea cucumber Holothuria arenicola extract against gastric ulcer in rats. J Basic Appl Zool. 2015;72:16-25.

19. Cornse SJ, Morrissey SM, Woods RJ. A method for the quantitative estimation of gastric barrier mucus. Proc Physiol Soc. 1974;242:116-7.

20. Mahmoud YI, El-Ghffar EA. Spirulina ameliorates aspirin-induced gastric ulcer in albino mice by alleviating oxidative stress and inflammation. Biomed Pharmacotherap. 2019;109:314-21.

21. Ohkawa H, Ohishi N, Yagi K. Assay for lipid peroxides in animal tissues by thiobarbituric acid reaction. Anal Biochem. 1979;95(2):359-64.

22. Sedlack J, Lindsay RH. Estimation of total protein-bound and non-protein sulfhydryl groups in tissue with Ellman's reagent. Anal Biochem. 1968;25:192205.

23. Clairbone A. Assay of catalase, in: R.A. Greenwald (Ed.), Hand Book of Method of Oxygen Free Radical Research. Boca Raton. 1985.

24. Marklund S, Marklund G. Involvement of super oxide anion radical in the auto oxidation of pyrogallol and a convenient assay for super oxide dismutase. Eur J Biochem. 1974;47:469-74.

25. Hoek JB, Pastorino JG. Ethanol, oxidative stress and cytokine-induced liver cell injury. Alcohol. 2002;27(1):63-8.

26. Dockmeci D, Akpolat M, Aydogdu N, Doganay L, Turan FN. L-Cartinine inhibits ethanol induced gastric mucosa injury in rats. Pharmacol Rep. 2005;57:481-8.
27. Babbs CF, Steiner NG. Detection and quantitation of hydroxyl radical using dimethyl sulfoxide as molecular probe. Methods Enzymol. 1990;186:137-47.

28. Singer TP, Kearney EB. Determination of succinic dehydrogenase activity. Methods Biochem Anal. 1957;4:307-33.

29. Hamdan D, El-Readi MZ, Tahrani A, Herrman F, Kaufman D, Farrag N, et al. Chemical composition and biological activity of Citrus jambhiri Lush. Food Chem. 2011;127(2):394-403.

30. Farzaei MH, Abdollahi M, Rahimi R. Role of dietary polyphenols in the management of peptic ulcer. World J Gastroenterol. 2015;21(21):6499-17. doi: 10.3748/wjg.v21.i21.6499.

31. Xueting M, Donghui X, Sika X, Yanping Z, Shibo X. Novel role of Zn (II)curcumin in enhancing cell proliferation and adjusting proinflammatory cytokine-mediated oxidative damage of ethanol-induced acute gastric ulcers. Chem Biol Interact. 2012;197(1):31-9.

32. Ajeigbe K, Oladejo E, Emikpe B, Asuk A, Olaleye S. The dual modulatory effect of folic acid supplementation on indomethacin induced gastropathy in the rat. Turk J Gastroenterol. 2012;23(6):639-45.

33. Hiraishi H, Terano A, Ota S, Mutoh H, Sugimoto T, Harada T, et al. Protection of cultured rat gastric cells against oxidant-induced damage by exogenous glutathione. Gastroenterol. 1994;106(5):1199-1207.

34. Sohair RF, Mahmoud AA, Mohannad H, Al-killidar N. Ameliorative effect of the sea cucumber Holothuria arenicola extract against gastric ulcer in rats. J Basic Appl Zool. 2015;72:16-25.

35. Ighodaro OM, Akinloye OA. First line defence antioxidants-SuperOxide Dismutase (SOD), Catalase (CAT) and Glutathione Peroxidase (GPX): Their fundamental role in the entire antioxidant defence grid. Alexandria J Med. 2018;54(4):287-93. Available online: https://doi.org/10.1016/j. ajme.2017.09.001.

36. Nakajima A, Yamada K, Zou LB, Mizuno M, Nabeshima T. Interleukin-6 protects PC12 cells from hydroxyoneal induced cytotoxicity by increasing intracellular glutathione levels. Free Rad Bio Med. 2002;32(12):1324-32.

37. Pitrowski J, Pitrowski E, Skrodzka D, Slomiany A, Slomiany BL. Gastric mucosal apoptosis induced by ethanol: Effect of antiulcer agents. Biochem Mol Bio Int. 1997;42(2):247-54.

38. Assimopoulou AN, Sinakos Z, Papageorgiou VP. Radical scavenging activity of Crocus sativus L. extract and its bioactive constituents. Phytotherap Res. 2005;19(11):997-1000.

39. Badria FA, Ibrahim AS, Badria AF, Elmarakby AA. Curcumin Attenuates Iron Accumulation and Oxidative Stress in the Liver and Spleen of Chronic IronOverloaded Rats. PLoS One. 2015;10(7):e0134156. https://doi.org/10.1371/ journal.pone.0134156.

40. Kapoor S, Priyadarsini KI. Protection of radiation induced protein damage by curcumin. Biophys Chem. 2001;92(1-2):19-126.

41. Jovanovic SV, Boone CW, Steenken S, Trinoga M, Kaskey RB. How curcumin works preferentially with water soluble antioxidants. J Am Chem Soc. 2001;123(13):3064-8.

42. Birben E, Sahiner UM, Sackesen C, Erzurum S, Kalayci O. Oxidative stress and antioxidant defense. World Allergy Organ J. 2012;5(1):9-19. doi: 10.1097/ WOX.0b013e3182439613.

43. Ruby AJ, Kuttan G, Babu KD, Rajasekharan KN, Kuttan R. Antitumour and antioxidant activity of natural curcuminoids. Cancer Lett. 1995;94(1):79-83.

44. Tuorkey M, Karolin K. Anti-ulcer activity of curcumin on experimental gastric ulcer in rats and its effect on oxidative stress/antioxidant, IL-6 and enzyme activities. Biomed Environ Sci. 2009;22(6):488-95.

45. Puurunen J. Gastric mucosal blood flow in ethanol-induced mucosal damage in the rat. Eur J Pharmacol. 1980;63(4):275-80. 


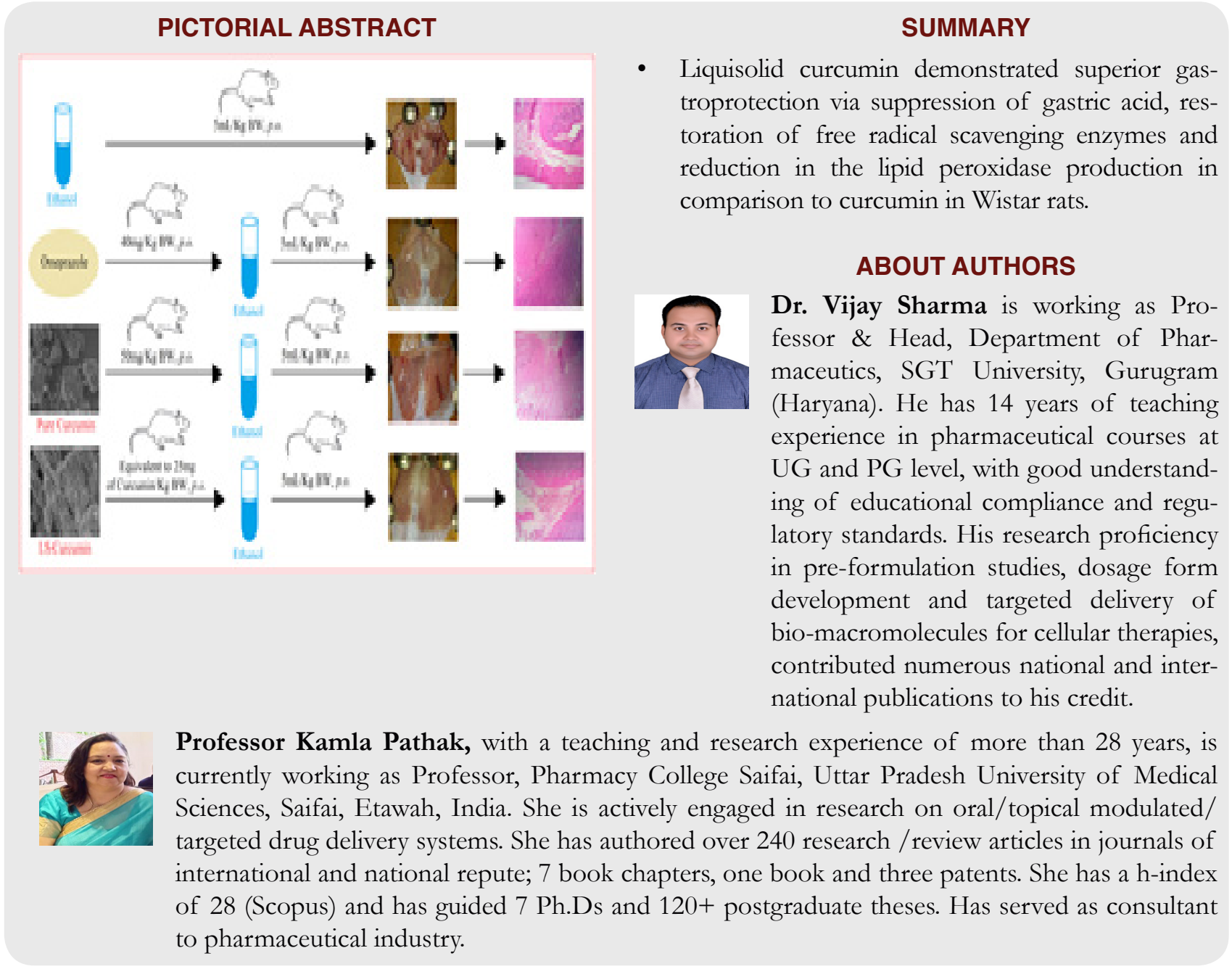

Cite this article: Sharma V, Pathak K. Investigating Gastroprotective Potential of Liquisolid Curcumin against the Role of Endogenous Aggressive Factors and Oxidative Stress Markers. Indian J of Pharmaceutical Education and Research. 2019;53(3):527-36. 